\title{
Study on the Cultivation Strategy of Anglo-American Culture in College English Teaching
}

\author{
Rui Xu \\ Xi'an University, School of Foreign Studies, 710065
}

\begin{abstract}
Keywords: College English; Teaching; Anglo-American culture
\end{abstract}
\begin{abstract}
The training strategies and methods of English teaching in the university and junior-high school stages are dissimilar. In college education, students usually ignore the study of Anglo-American culture. Lacking knowledge of this part easily leads to the barriers of cultural feelings and misunderstanding of cultural concepts for students in English communication. Therefore, with the deepening of English learning and the strengthening of international cooperation, college English teachers should focus on strengthening students' learning and understanding of Anglo-American culture. On the other hand, teachers should also be aware of the importance of Anglo-American cultural communication.

English teaching cannot be separated from the explanation and introduction of the cultural origins.
\end{abstract} Since ancient times, language and culture are two inseparable carriers. The production, formation, development and final extinction of a country's or nation's language are associated with the culture of this country or nation. Learning a new language requires a deep understanding of the culture of this country or nation as the feelings of this country's culture can help us understand the deep and extended meanings of the language better and more thoroughly. The baptism of language learners through culture allows them to perceive the feelings behind the text. While reading foreign language books or seeing foreign language films, you can vicariously feel what the author wants to convey. Therefore, in college English teaching, it is necessary to introduce Anglo-American culture. At the same time, teachers should ask students to compare and find the differences between Chinese and Anglo-American culture, and explore the reasons for the formation of differences, tracing the source, thus to find the sources of three cultures.

In the past college English teaching, because of lack of advanced teaching equipment and excellent teacher resources, colleges and universities usually use the similar teaching methods with the junior high school, which mainly focus on the training of listening, reading, writing and other English skills. Through each branch of the class, teachers can find the strengths of students, and then classify the students to different types for training. In the past, due to the insufficient national economic strength, the government subsidy to colleges and universities is not enough. Therefore, in the process of English education, students rarely have the opportunity to go abroad and truly feel the practical charm and practical skills of the language in the English-speaking countries, but only reinforce their English skills through the traditional teaching methods. With the acceleration of the process of opening to the outside world, foreign-funded enterprises come to China to invest and build factories in China. Limited to the traditional cultivating mode, while communicating with English native speakers, Chinese people may encounter the conditions such as communication barriers. In the process of writing terms and projects, due to cultural differences, the project progress might be delayed, which will seriously lead to the failure of the entire cooperation. Therefore, colleges and universities should be based on the current situation to reform the college English teaching and training system and pay attention to the study of Anglo-American culture. With the reform of the national education system, heads of the universities and the Ministry of Education have paid more and more attention to the importance of Anglo-American culture in college English education. Therefore, the Ministry of Education has stipulated that in the college English teaching curriculum, the course of Anglo-American culture is included into the syllabus system, thus training students to learn and apply with full vigor, so as to truly learn a language and its cultural connotation and communicate with foreigners without any barriers. With the development of science and technology and the acceleration of education and training system 
reform, colleges and universities should explore that in order to allow students to experience and truly feel the Anglo-American culture in college English teaching, what kind of the strategies should be generated.

\section{The Current Problems in the Cultivation of Anglo-American Culture in College English Education}

\section{English Teaching Contents Were Mostly Grammar Translation Method and Sentence Practice of Structuralism During 1960-1970}

In the early years of English teaching in our country, the English teaching content remained at the level of grammar translation and structuralism. Until 1980, the discussion of language communication began to appear in English teaching content. Thus, English teaching started late in China's university education level; and the teaching of cultural content began to be a few steps later than other countries. China's English education, whether in the high school stage, or in the university higher education stage, is mainly the test-oriented education. Teachers asked students to remember English words, understand the English sentences, and pay attention to the English grammar written norms. Besides, in English writing, teachers request students to use high-end vocabulary and sentence patterns, but ignore if their writing logic is coherent, and even pay less attention to the practical application of English. With the development of science and technology and economic globalization, international co-operations are becoming more and closer. As an international language, English is becoming more and more important in international cooperation and communication. When dealing with international crises and regional issues, the importance of English culture has become increasingly prominent. Therefore, our country requires colleges and universities to set up Anglo-American cultural related courses to strengthen the English majors on the understanding and familiarity of cultures for English speaking countries. However, in reality, on the one hand, because of the limitations of the university teachers' own cultural backgrounds, not all the teachers at colleges and universities have the opportunity to go abroad as a visiting scholar. Therefore, Anglo-American culture cannot be taught systematically and specifically. On the other hand, due to the unreasonable setting of university courses and curriculum system, it is unable to provide foreign internship and foreign summer camp experience activities for every student, and thus cannot make students feel the Anglo-American culture.

\section{Irrational Existing College English Education Training System and Its Unawareness of Anglo-American Cultural Education}

Students in China learn English from an early age. Until university stage, it is found that the sentences they used to say when they were young such as "How old are you?", "How do you do?" are personal privacy for foreigners. When learning English from an early age, the English teacher will tell us how to start a conversation by asking the name, age and mood of the foreigner. However, the questions are meaningless and tedious for foreigners. On the contrary, foreigners will be more inclined to the discussion of the weather in the daily communications and greetings. There are also differences in ways of thinking for British and American people and Chinese people. Chinese people are accustomed to implicitly express personal feelings or thoughts, while British and American people like to express their views directly. For example, Chinese people often modest reply "no no, I have a lot of shortcomings and need to be improved." when they are praised by someone, but British and American people will directly say "Yes, I am very good. I know. Thank you." The differences between Chinese and Anglo-American cultures may cause misunderstandings during the communications between Chinese and Anglo-American people, thus leading to contradictions between the two sides. Therefore, teachers should be aware of the above issues objectively in the process of teaching English so as to improve the teaching methods and teaching content. As the current college English education and training system is unreasonable, Anglo-American culture and education are given insufficient attention. In the current college English teaching, teachers still emphasize vocabulary and grammar, while in reading 
comprehension, they have not completely transformed to forms of examination in foreign counties, which make students to obtain high scores in the IELTS and TOEFL test in reading and listening but low scores in composition and TSE. In fact, the composition of low score is because the way of thinking of students, of which the logic is not strong, is not convergent with that of British and American people. Therefore, learning Anglo-American culture not only helps us understand the thinking logic structure of British and American people, but also help us better communicate with them.

\section{Students' Unawareness of Anglo-American Culture}

In real life, on the one hand, due to the unreasonable system, the teacher's teaching content is not scientific, ignoring the transmission of Anglo-American culture; but on the other hand, more importantly, the students themselves do not pay attention to Anglo-American culture. As students do not understand the role of Anglo-American culture in their study, they do not have a genuine sense of love for English. Therefore, when students learn about English culture, they only understand or stay on the surface without digging deep essence. Many English words and phrases have a lot of slang expressions; or in conjunction with specific contexts, words can have a unique meaning. For example: in the expression the meaning of right, we habitually use "Yes", but in the Anglo-American daily expression, they prefer to use "Yep or Yup". For another example, many times in the understanding of the phrase, we only stay in the shallow meaning of the word, or on the word meaning, many Chinese people first translated "work like a horse" on the word meaning, which is thought provoking that why it is expressed like this, where the particularity of horse work is. In fact, in the Anglo-American culture, they used to compare the cattle as a horse, so the really meaning of the sentence is "working as diligent as cattle without any complaints. In fact, in the process of English learning, students should know more about the expressions of slangs. In communication with the British and American people, a large number of slang uses will bring closeness to both sides.

\section{Developing Anglo-American Culture Training Methods and Extending College English Teaching System}

With the continuous development of economy and the reform of China's education system, in college English education, colleges and universities should absorb advanced educational ideas, comprehensively use high-tech education and strengthen international exchanges. Therefore, it is necessary for colleges and universities to expand the English teaching system, reform the existing educational system, effectively establish the Anglo-American cultural curriculum, and cultivate students' understanding and contact with different cultures, thus to avoid cultural conflicts and cultural barriers in the process of communication with international friends. During the participation of Anglo-American cultural courses, students can not only find the differences between Anglo-American culture and traditional Chinese culture, but also enhance their own cultural identity and cultural inclusiveness. Students can also know more about the customs and humanities knowledge of Anglo-American countries through learning the Anglo-American culture.

\section{Exploring the Cultural Connotation of English Textbooks}

In the process of college English teaching, when preparing a unit, teachers should explore much of the cultural connotation of teaching materials, which should not only stay in the vocabulary meaning, sentence characteristics and sentence introduction and so on. When preparing an English reading, teachers should consult the relevant background through different ways. In the classroom teaching, they should introduce the context of the article and the author's own experience, which should be similar to our Chinese language and literature teaching mode, thus to make students know context in which this article was written, so as to help students understand the full text. Besides, the teacher should also strengthen the training of the students' self-exploration of textual culture 
connotation. Teachers should require students to read the relevant literature before class through which to strength students' understanding of Anglo-American culture, expand the horizons of students, and improve students' English literacy, thus to make students really learn to know and learn to use, transforming the connotation of textbooks into their own cultural literacy.

\section{Using Modern Multimedia Teaching Methods}

With the change of science and technology, the teacher's teaching form also changes with the times. From the previous completely relying on the blackboard classroom teaching model, it gradually becomes a combination of multimedia and blackboard vivid teaching methods. Up to now, with the exploration of classroom teaching effectiveness and fun of continuous, in college English teaching, teachers should pay more attention to teaching methods selection. On the one hand, the comprehensive use of video recorders, slides, projectors and other modern multimedia teaching methods can increase the initiative and enthusiasm of the students. On the other hand, it can subtly influence on way of transmitting foreign languages of students engaged in education or work in the future. The college English teaching is a comprehensive education system. Teachers can allow students to see the films via modern multimedia teaching methods to let students truly feel Anglo-American culture through real and vivid touch of the screen. This way is different from pure texts which are boring and abstract reading. At the same time, the teacher can require students to write English script through using VCR or DV and other video equipment, and then play the script out. This kind of form can make students participate in teaching, which is more conducive for students to feel Anglo-American culture and improve oral English expression.

\section{Guiding Students to Start Extracurricular Reading Activities}

University education is different from the junior high school education. Teachers should guide students to start the Anglo-American cultural extracurricular reading activities. In the current model of university training, students are unable to fully understand the knowledge due to the limited amount of time and faculty. Therefore, in the summer and winter vacation, teachers should ask students to read the Economist, China Daily and other foreign journals, or listen to BBC News Broadcasting every day to understand the current real-time information of Anglo-American countries to through intuitive contact with foreign journals and radio. As college students in new era, students learning Anglo-American knowledge should not only stay in the textbook level. With the help of developed Internet technology, students can use a variety of app or weico to know more information and achieve mastering whatever you learnt and loving whatever you are engaged in. Students can learn from different sources of knowledge to improve their own Anglo-American cultural literacy, hence enhance their interest in learning Anglo-American culture and strengthen the ability of thinking and analysis of foreign events.

\section{Guiding Students to Understand the Anglo-American Culture}

In the moment of the rapid development of Internet technology, college teachers should change the traditional college English teaching mode through various channels, improve the teaching style, guide students to understand the Anglo-American culture, and enhance students' interest in Anglo-American culture. First of all, with the continuous improvement of China's economic strength, the government should provide more financial support for colleges and universities and provide better personnel training policies. The English majors should be provided regular foreign exchange learning opportunities. After living and studying in Britain and America for some time, being influenced by the local culture, students can naturally enhance their awareness of the Anglo-American culture. This direct way is stronger than reading hundreds of books or browsing foreign language films, which can eliminate all the centre of cultural barriers to make students have immersive experience of foreign culture, so as to understand the differences between Chinese and Anglo-American culture. After coming back to China, students can share their feelings to others. 
This first-hand data and first-hand experience are convincing stronger than other information, which make English majors in colleges and universities desire to go out and learn about Anglo-American culture in this way. On the other hand, the teacher should change the prejudice against film teaching and drama teaching. Traditional teaching methods may be rooted in the hearts of university teachers, however, with the scientific and technological changes, teachers should make the innovation of teaching model and enhance student learning initiative by play relevant movies in the classroom and examine students' oral expression and writing ability through the way of drama.

\section{Conclusion}

With the strengthening of international integration trend, international exchanges and cooperation have increased. College English teaching should follow the trend of change and direction to reform the existing teaching model and improve the existing teaching system. Teachers should guide students to implement extracurricular reading activities and know about Anglo-American culture by exploring the cultural connotation of English textbook and using modern multimedia teaching methods, comprehensively promoting the permeation and touch of Anglo-American culture and the importance of Anglo-American culture for students, thus understanding the differences between Chinese and Anglo-American culture so as to obtain international insight

\section{References}

[1] M. Jin: Study on the cultivation strategy of English and American culture in college English teaching. Overseas English, Vol. 07 (2012), p. 93. (In Chinese)

[2] X.Y. Wang: Cultivation of cross-cultural awareness in college English teaching. Heilongjiang Science and Technology Information, Vol. 01 (2011), p. 172. (In Chinese)

[3] D.H. Yang: College English teaching reform and strategies for cultivating intercultural communicative competence. Journal of Changchun Institute of Education, Vol. 02 (2011), p. 125. (In Chinese)

[4] H. Liu: Intercultural Communicative Competence and College English Teaching. Journal of Hotan Teachers College, Vol. 02 (2011), p. 125. (In Chinese)

[5] B. Huang: College English teaching in the penetration of English and American culture strategy. Intelligence, Vol. 35 (2011), p. 82. (In Chinese)

[6] Y.J. Li: Study on the problems and strategies of cultural input in college English teaching. English Square (Academic Studies), Vol. 03 (2013). (In Chinese)

[7] J.F. Shang, Q.C. Li: College English teaching students' cross-cultural communication ability training strategy. Education Exploration, Vol. 03 (2013), p. 43. (In Chinese)

[8] G.L. Li: The introduction and strategy of native culture in college English teaching. Journal of Educational Theory and Practice, Vol. 18 (2014), p. 57. (In Chinese)

[9] S.N. Sun, L.S. Xu: Research on computer - driven cross - cultural ability training in college English teaching. Foreign language circles, Vol. 04 (2014), p. 89. (In Chinese)

[10]A. Gao: Cultivation of cross-cultural awareness in college English teaching. Reform and Opening Up, Vol. 18 (2010), p. 159. (In Chinese)

[11]J.F. Ma: College English teaching and the cultivation of intercultural communicative competence. Journal of Chengdu University (Educational Science Edition), Vol. 04 (2007), p. 50. (In Chinese)

[12]D.J. Gao, H.B. Shen: The principles and methods of British and American cultural knowledge in college english teaching. Journal of Changchun Normal University, Vol. 07 (2007), p. 129. (In Chinese) 